\title{
Treasury Single Account as a Tool for Managing of Public Finances in Nigeria
}

\author{
Kabiru Ibrahim*, Sirajo Abdullahi Isah, Abubakar Adamu Jahun \\ Department of Accounting, Faculty of Management Technology, Abubakar Tafawa Balewa University, Bauchi
}

DOI: $10.36348 /$ SB.2019.v05i12.004

| Received: 20.11.2019 | Accepted: 27.11.2019 | Published: 17.12.2019

*Corresponding author: Kabiru Ibrahim

Abstract

The Treasury Single Account (TSA) was recently implemented fully in the Nigerian economy by the present government in order to ensure prudence and probity in the management of financial resources. With the TSA government expects to block all loopholes and leakages of financial resources of the government and also ensure a robust financial management system. Mismanagement of public funds, corruption and other financial irregularities has been described as the greatest challenges of our time and their prevalence in governance has been identified as one major obstacle militating against rapid growth and development. TSA is a unified structure of government bank accounts enabling consolidation and optimal utilization of government cash resources. It is a bank account or a set of linked bank accounts through which the government transacts all its receipts and payments and gets a consolidated view of its cash position at any given time. The Federal Government's directive to all revenue-generating agencies to close their accounts with commercial banks by February 28, 2015 and transfer same into a Consolidated Revenue Fund of the Federation and Treasury Single Account as a new electronic revenue collecting platform implemented recently by President Buhari has continued to generate debate across the country. This study examines the benefits of TSA as a tool for managing Public Finances and benefit government derived in implementing TSA in Nigeria and concludes that, proper implementation of TSA has helped tremendously in curbing mismanagement of Public finances, corruption, block leakages and other financial irregularities in the country.

Keywords: Treasury Single Account, Management Theory, Public Finance and Public Finance Management.

Copyright @ 2019: This is an open-access article distributed under the terms of the Creative Commons Attribution license which permits unrestricted use, distribution, and reproduction in any medium for non-commercial use (NonCommercial, or CC-BY-NC) provided the original author and source are credited.

\section{INTRODUCTION}

\section{Background to the study}

The challenge facing most parts of the world and particularly the developing countries like Nigeria is how to achieve efficient allocation of resources as well as the stabilization of the business cycles [1]. This stabilization requires an important factor for efficient management and control of government's cash resources which is based on unified structure of government banking [2]. Such unified banking arrangements should be designed to minimize the cost of government borrowing and maximize the opportunity cost of cash resources. Several policies and strategies have been put in place by previous administrations on how to ensure effective and efficient management of public finances in Nigeria but on avail, part of which is the introduction of Treasury Single Account (TSA) which if well implemented is believed to serve as a panacea of mismanagement of public funds.
TSA formally became operation on April 2, 2012 following the go-live of Government Integrated Financial Management Information System (GIFMIS). Against the foregoing background have emerged the leadership of President Buhari with widely acknowledged distinctive leadership character, integrity and zero tolerance of corruption, along with an observable disposition towards an ethos of putting the interest of the collective over and above that of the individual. In fact, he has defined corruption as the greatest form of human right violation and just within the short span of three months; his body language has produced positive result [3]. It is also with this spirit that directive were given to all ministries, department and agencies on total compliance to the treasury single account that was hitherto introduced by the last administration but with little or no compliance. 
Treasury single account is a public accounting system under which all government revenue, receipts and income are collected into one single account, usually maintained by the country's central bank and all payments done through this account as well. The philosophical underpinning of TSA is primarily to ensure accountability of government revenue, enhancing transparency and avoid misapplication and mismanagement of public funds. The different TSA account types include main account, transaction account; zero balance account, impress account, transit account and correspondence accounts for different transaction purposes. TSA helps check incidence of multiple accounts operated by government ministries, department and agencies (MDAs) foe collection and spending of government revenues.

\section{Statement of the Problem}

Nigeria is a country endowed with natural and human resources, but still fall short of the developmental progress required to positively impact on the well being of the average Nigerian. Mismanagement of public funds, corruption and other financial irregularities has been described as the greatest challenges of the present time and the prevalence in governance has been identified as one major obstacle militating against rapid growth and development [4]. More so, there are numerous corrupt practices that exist in the Country's public accounting system, lack of transparency and accountability [5].

Therefore, the problems stated above are mostly owing to the fact that why Nigerians average are not enjoying the impact our resources and as a result of mis-management of public finance.

\section{OBJECTIVE OF THE STUDY}

The general objective of the study is to assess the Treasury Single Account as a tool for managing public finances in Nigeria. The specific objective may comprised:

- To ascertain the effect of TSA in managing public finance

- To examine benefit government derived in implementing TSA on revenue administration and cash balances.

\section{LITERATURE REVIEW Conceptual Review}

Treasury Single Account: Treasury Single Account is a public accounting system under which all government revenue, receipts and income are collected into one single account, usually maintained by the country's Central Bank and all payments done through this account as well.

Chukwu [6] define Treasury Single Account (TSA) as a network of subsidiary account linked to a main account such that, transactions are effected in the subsidiary accounts but closing balances on these subsidiary accounts are transferred to the main account, at the end of each business day.

Public Finance: Deals with the provision, custody and disbursement of resources needed for conduct of public or government function.

Public Finance Management: It encompasses all the activities involved in resource generation, resources allocation and expenditure management in government in order to achieve efficient and effective delivery of public goods and services.

\section{Empirical Review}

TSA is a public accounting system under which all government revenue, receipts and income are collected into one single account, usually maintained by the country's Central Bank and all payments done through this account as well. It is unified structure of bank accounts enabling consolidation and optimal utilization of government's cash resources. Onyekpere [7] opined that TSA is a process and tool for effective management of government's finances, banking and cash position. In accordance with the name, it pools and unifies all government accounts through a single treasury account. Chukwu [8] defined a treasury single account (TSA) as a network of subsidiary accounts all linked to a main account such that, transactions are effected in the subsidiary accounts but closing balances on these subsidiary accounts are transferred to the main account, at the end of each business day. According to Otunla (former Accountant General of the Federation) prior to TSA, Nigeria had fragmented banking arrangements for revenue and payment transactions. He stated that, "There were more than 10,000 bank accounts in multiple banks, which made it impossible to establish government consolidated cash position at any point in time. This led to pockets of idle cash balances held in MDAs' accounts when government was out borrowing money" [9]. The idea of Treasury Single Account came into being when some Agencies refused to declare and remit the $25 \%$ of their annual revenue they generated to the treasury as demanded by law. In 2012 about N120 billion was forcefully collected by government from MDAs (Ministries, Departments and Agencies) being $25 \%$ of their gross revenue to the treasury with another N34 billion collected in 2013. Before then, most of the MDAs were reluctant to remit the requested amounts by law to the treasury.

According to Adeolu [10] treasury single account is a public accounting system under which all government revenue, receipts and income are collected into one single account, usually maintained by the country's Central Bank and all payments done through this account as well. The maintenance of a Treasury Single Account will help to ensure proper cash management by eliminating idle funds usually left with 
different commercial banks and in a way to enhance reconciliation of revenue e-collection and payment [10]. Hamisu [11] buttressed that The Revenue Mobilization and Fiscal Commission released an audit report which indicted some banks for withholding about N12b revenue collected on behalf of the Nigerian Customs Service and Federal Inland Revenue Service. The revenue according to the commission was stashed in 19 banks from January 2008 to June 2012. The chairman, Non- Oil Committee of the

Commission, Rev Ajibola Fagboyegun demanded for urgent return of the funds by the banks to avoid sanctions. It is eminent at this point to note that the TSA issue did not start with Buhari's administration. Former President Goodluck Jonathan initiated the policy in 2014. But he could not implement it before he left office on May 29, 2015. According Okechukwu, Chukwurah, Daniel, \& Iheanacho, 2015; Obinna, 2015 beyond transparency and accountability, the TSA will introduce 'efficiency'into overall management of public finances and this will in the long run lead to effectiveness of government spending since it places government in a better position to realize overall policy goals.

How does TSA operate?: For TSA to work effectively, he opined that there must be daily clearing of and consolidation of cash balances into the central account even where the MDA's accounts are already held at the CBN such as the FIRS. Some may argue that it is necessary to separate the cash transactions of each MDA for control and reporting purposes; however, this objective can be achieved through proper accounting rather than by holding cash in separate bank accounts. In any case, the various bank accounts held by MDAs in commercial banks do not necessarily have to be closed, but they must be operated at Zero-Balance Accounts where any closing balance must be swept to TSA at the Central Bank of Nigeria (CBN) on a daily basis to give government a consolidated cash position. He continued that TSA can therefore cover all funds including earmark and extra-budgetary accounts or even funds held in trust by government. To make this work, accounting systems must be robust and capable of accurately distinguishing trust assets in the TSA. This is not different from what a private company operating in many states or even internationally will do to consolidate its funds rather than fragment them by divisions or sub-entities. Hence, a company will only borrow externally if and only if its overall cash position is negative rather than when a division has a deficit even though others may have surpluses. Odekule [3] quickly pointed out that TSA is not a new concept; it has been adopted for decades in many countries both in the developed world such as the United States, UK, France and developing economies like India and Indonesia.

\section{Theoretical Framework}

A number of socio-economic theories were adopted to form a solid foundation for the concept of TSA, some of which include stakeholder theory, public finance management theory, incremental model and modern money theory.

\section{Who is a stakeholder?}

Phillips [12] identifies a firm's legitimate (or normative) stakeholders as those groups to whom the firm owes an obligation based on their participation in the cooperative scheme that constitutes the organization and makes it a going concern. A central premise of much of the literature on stakeholder theory is that focusing on stakeholders, specifically treating them well and managing for their interests, helps a firm create value along a number of dimensions and is therefore good for firm performance is generally supportive of a positive relationship between stakeholder-oriented management and firm performance, which is almost always measured in terms of financial returns.

Freeman [13] defines them as "those groups without whose support the organization would cease to exist". Freeman [13] has continued to use this definition in a modified form: "those groups who are vital to the survival and success of the organization". Financial performance is important to many of a firm's stakeholders, but it is not the only aspect of value that is important to stakeholders.

\section{Stakeholder theory}

This theory was popularized by Richard Edward Freeman in 1984, the book -Strategic Management: A Stakeholder Approach came out. He indicated that his view of the stakeholder concept was done from the perspective of the company. The word stakeholder was however pioneered by the work done by Stanford Research Institute in the 1960s. Stakeholder theory looks beyond the relationship between shareholders and managers to include other categories of stakeholders such as customers, suppliers' etc. corporate governance efforts should be geared towards empowering those stakeholders who contribute or control resources and skills and to ensure that the interests of these stakeholders are aligned [8]. According to Mikailu and Garbu [14], this theory considers the firm as a chain of contracts between management and shareholders on the one hand and employees, shake holders, creditors, government; in public sector, citizens, other government, international bodies etc. thus, from the point of view of the stakeholder theory, concern should go beyond the traditional management shareholder (government citizen) relationship to include all other stakeholders. Freeman [13] posits that the idea of stakeholders, or stakeholder management, or a stakeholder approach to strategic management, suggests that managers must 
formulate and implement processes which satisfy all and only those groups who have a stake in the business, relating this to the public sector, policies and processes formulated should satisfy public servants, taxpayers, other government, international bodies etc. The stakeholder theory, in essence, suggests that every organization strives to create value for all stakeholders as a reason for its existence.

\section{Stakeholder theory and TSA}

The theory assumed that adoption of treasury single account by the federal government is as a result of the pressure from stakeholders (citizens, public servants, taxpayers, international bodies etc.) against corruption and improper management of government money. It is as a result of the concerns and expectations of powerful stakeholders that lead to TSA response. The citizens are the stakeholders and in other to maximize their interest based on the stakeholder theory, TSA was adopted.

\section{Public Finance Management theory}

This theory assumed that all areas of financial resources, i.e. mobilization and expenditure should be well utilized in government for the benefits of the citizens. It involves resource mobilization, prioritization of programs, the budgetary process, efficient management of resources and exercising control to guide against threats. TSA basically is to prevent misuse of public funds [15].

\section{METHODOLOGY}

The descriptive survey design was adopted for this study. It implies that the variables of interest in this study have been studied before, either independently, as in an exploratory study, or with other variables, so there is sufficient information to ask a question about the relationship between them. The questionnaire was used to collect data for this study. This research design is appropriate for achieving the objectives of the study.

\section{The Population of the study}

For the purpose of this study, the population included the staff of some federal government parastatals including Federal In land Revenue Service, Federal Immigration Service, Federal Customs Service, Corporate Affairs Commission, and Federal Medical Centre that are located in Bauchi state. Due to the nature of the research topic, only the staff in the accounting department of each parastatal was considered as respondents.

\section{DATA ANALYSIS AND INTERPRETATION OF RESULT}

Table-1: Shows the number of the population of the study as drawn from the four Federal Government institutions.

\begin{tabular}{rlc}
\hline S/N & Name of institutions & Number of staff \\
\hline 1. & Federal Inland Revenue Service & 20 \\
2. & Federal Immigration Service & 20 \\
3. & Federal Customs Service & 20 \\
4. & Corporate Affairs Commission & 20 \\
Total & & 80 \\
\hline
\end{tabular}

Research question 1: to what extent does the effect of TSA on managing public finance?

The summary of the simple regression analysis as shown in Table 2 below indicates that the effect of TSA on managing public finance to have significant improvement. This is shown by the regression coefficient $(\mathrm{R}=.82)$ and the coefficient of determination $(\mathrm{R} 2=.68) .4 .1 .2$

Table -2: Summary of simple regression analysis, on the effect of TSA in managing public finance

\begin{tabular}{|c|c|c|c|c|}
\hline & & B & SE B & \\
\hline Constant & & 4.93 & .06 & \\
\hline Effect & & -.49 & .02 & -.82 \\
\hline $\mathrm{R}$ & .82 & & & \\
\hline $\mathrm{R} 2$ & .68 & & & \\
\hline Adj.R2 & .68 & & & \\
\hline $\mathrm{F}$ & 542.87 & & & \\
\hline
\end{tabular}

Research question 2: What benefits government can derive in implementing TSA on revenue administration and cash balances? 
Table 3. Summary of simple regression analysis on the extent of benefits derive by government in implementing TSA on revenue administration and cash balances.

\begin{tabular}{lcccc}
\hline & & B & SE B & $\beta$ \\
\hline Constant & & .88 & .23 & \\
Effect & .49 & -.66 & .07 & .49 \\
$\mathrm{R}$ & .24 & & & \\
$\mathrm{R} 2$ & .23 & & & \\
Adj.R2 & 79.05 & & & \\
$\mathrm{~F}$ & 79 & & \\
\hline
\end{tabular}

The simple regression analysis in Table 3 above shows the regression coefficient $(\mathrm{R}=.49)$ and the coefficient of determination $(\mathrm{R} 2=.24)$. This indicates that TSA affect revenue administration and cash balances of government to a moderate extent since unexpected explained $24 \%$ of the variance in effect in the TSA.

\section{Test of Hypotheses}

Hypothesis

Implementing TSA has no significant effect on managing public finance.

Table -4: Test of Significance of Simple Regression Analysis on the extent to which Implementation of TSA has affected the managing public finance in Nigeria.

\begin{tabular}{|c|c|c|c|c|c|}
\hline & & B & SE B & $\beta$ & $\mathrm{P}$-value \\
\hline Constant & & 4.93 & & .06 & .00 \\
\hline Effect & & -.49 & .02 & -.82 & .00 \\
\hline $\mathrm{R}$ & .82 & & & & \\
\hline $\mathrm{R} 2$ & .68 & & & & \\
\hline Adj.R2 & .68 & & & & \\
\hline $\mathrm{F}$ & 542.87 & & & & .00 \\
\hline
\end{tabular}

As shown in Table 4above, the simple regression coefficient $(\mathrm{R})$ is .82 while the $\mathrm{R} 2 \mathrm{is} .68$. The F-ratio associated with these is 542.87 and the P-value $=.00$, since $\mathrm{P}$-value is less than the stipulated 0.05 level of significance, it was decided that TSA Implemented by government has a significant effect on managing public finance in. The null hypothesis was therefore rejected.

Hypothesis two: TSA has no significant effect on revenue administration and cash balances of government.

Table-5: Test of significance of simple regression analysis on the extent to which TSA has no significant effect on revenue administration and cash balances of government.

\begin{tabular}{|c|c|c|c|c|c|}
\hline & & B & SE B & $\beta$ & $\mathrm{P}$-value \\
\hline Constant & & .88 & & .23 & .00 \\
\hline Effect & & .66 & .07 & .49 & .00 \\
\hline $\mathrm{R}$ & .49 & & & & \\
\hline $\mathrm{R} 2$ & .24 & & & & \\
\hline Adj.R2 & .23 & & & & \\
\hline $\mathrm{F}$ & 79.05 & & & & .00 \\
\hline
\end{tabular}

The summary of simple regression analysis displayed in Table 5 above shows the regression coefficient $(\mathrm{R})=.49, \mathrm{R} 2=.24$, while F-ratio $=79.05$ and $\mathrm{P}$-value $=.00$. Since the P-value is less than the stipulated 0.05 level of significance, it was decided that TSA has a significant effect on revenue administration and cash balances of government.

\section{RESULT AND DISCUSSION}

The first research question shows the simple regression analysis as shown in Table 4 indicates that proper implementation of TSA affect revenue administration and cash balances of government to a great extent. This is shown by the regression coefficient $(\mathrm{R}=.82)$ and the coefficient of determination $(\mathrm{R} 2=$ .68). This is in line with the study of Deniel \& Iheanacho (2015) who opined that Treasury Single Account policy would go a long way in blocking the financial leakages. The hypothesis one indicates that there is a significant effect on Single Treasury Account (TSA) on revenue administration and cash balances of government. This is also proved with simple regression coefficient $(\mathrm{R})$ as .82 , while the $\mathrm{R} 2$ is .68. The F-ratio associated with these is 542.87 and the P-value $=.00$, since P-value is less than the stipulated 0.05 level of significance, it was decided that TSA has a significant 
effect on revenue administration and cash balances. The null hypothesis was therefore rejected.

The second research question shows that simple regression analysis in Table 5 shows the regression coefficient $(\mathrm{R}=.49)$ and the coefficient of determination $(\mathrm{R} 2=.24)$. This indicates that unforeseen predicament affect revenue administration and cash balances to a moderate extent since unforeseen predicament explained $24 \%$ of the variance in accountability in the government. This is in support by Iroegbu 1. (2018) that there are some unexpected reactions and counter-reactions to this new policy of government. This is shown by simple regression analysis displayed in Table 5 on the regression coefficient $(\mathrm{R})=.49, \mathrm{R} 2=.24$, while $\mathrm{F}$-ratio $=79.05$ and P-value $=.00$. Since the P-value is less than the stipulated 0.05 level of significance.

The result and findings also shows the followings benefit that will derive in future for proper implementation of TSA:

i. It allows Complete and Timely Information on Government Cash Resources

ii. Improves Appropriation Control: The TSA ensures that the Ministry of Finance has full control over budget allocations, and strengthens the authority of the budget appropriation.

iii. Enables Efficient Cash Management. A TSA facilitates regular monitoring of government cash balances. It also enables higher quality cash outturn analysis to be undertaken

\section{CONCLUSION}

The study has examined the effect of Treasury Single Account on public fund management in Nigeria. The Treasury Single Account has significance impact on the accountability, transparency and financial leakages of public funds. It is obvious that the primary objective of a TSA is to ensure effective aggregate control over government cash balances. It avoids borrowing and paying additional interest charges to finance the expenditures of some agencies while other agencies keep idle balances in their bank accounts. Findings of this study, therefore, provide insight into the Treasury Single Account on public fund management. The study concludes that Treasury Single Account is a tool for effective management of public fund.

\section{RECOMMENDATIONS}

- There is the need to improve the revenue base of the country through full implementation of TSA so as to block of all identified leakages and improve the efficiency of revenue administration.

- Government should engross in immense public enlightenment and clarification around the significance of the policy to nurture its success.
- The ability of the Federal Ministry of Finance and the CBN should be overhauled by the government to cope with challenges associated with the enforcement of the provisions of the TSA.

- The government should shelter as soon as probable the appropriate statutory support to aid the appropriate regulatory atmosphere which will drive the effective implementation of the TSA.

- The government should analysis the TSA policy to precisely safeguard the financial sovereignty of the Nigerian educational institutions.

- The legal framework should be reviewed and modified where obligatory while training should be provided to relevant staff of CBN and MDAs to ensure resourceful implementation.

- The FIRS and Joint Tax Board should accelerate the implementation of their e-filing schemes which should help ultimately in ensuring that immediate credits are granted to taxpayers for remittances to TSA via commercial banks.

- There is the need to improve the revenue base of the country through full implementation of TSA so as to block of all identified leakages and improve the efficiency of revenue administration.

- Government should engross in immense public enlightenment and clarification around the significance of the policy to nurture its success.

- The ability of the Federal Ministry of Finance and the CBN should be overhauled by the government to cope with challenges associated with the enforcement of the provisions of the TSA.

\section{Implication of the study}

This study will enlighten the general public on the benefits of Treasury Single Account to the managing of public finance in Nigeria and serve as an input to policy makers in decision making concerning management of public finance. This research will also contribute to other scholars and researchers interested in carrying out further research in the field.

\section{REFERENCE}

1. Meyer, W. (2018). Treasury single account and public fund management. International journal of scientific and engineering research, 9(12); 77-82

2. Iroegbu, 1. (2018). Treasury Single Account (TSA) and transparency in public sector financial management in Nigeria. Journal of Accounting and Financial management, 4(6): 67-70

3. Odekule, J. (2016). 15 things to know about TSApremium Times.

4. Abdulrasheed, B. (2016). The Treasury Single Account (TSA) and Nigeria Economy between 1999 and 2015 an assessment: Journal of Accounting and financial management 2(6), 61-75

5. Nwoargu, I. (2015). An overview of the treasury single account. Retrieved from placing: http://placing.org/legist/an-overview-of-the- 
treasury-single-account-tsa/ Access on October, 2019.

6. Chukwu, O. (2016). Treasury Single Account (TSA), Prospect and Problem. Research journal of finance and accounting, 7(3), 34-38.

7. Oyekpere. (2015). Buhari and the Treasury Single Account, Daily Trust, 27 September 2015, P22.

8. Nwachukwu. (2015). "TSA: We're not aware of REMITA's charge, Accountant General". www.vanguardnewspaper.com Retrieved 22 October 2019.

9. Obinna. (2015). Implementation of TSA and Nigeria Economy. Chairman National Planning Commission. Nigeria. (Unpublished Paper)

10. Adeolu, A. (2015): "things to know about Treasury Single Account (TSA)". Retrieved 4 October, 2016.

11. Hamisu. (2015). The Treasury Single Account (TSA) as an Instrument of Financial Prudence and Management: Prospects and Problems. Research Journal of Finance and Accounting, 7(4), 66-71.

12. Phillips. (2003). Treasury Single Account Practices in ECA, mimeo.
13. Freeman. (2004). "Payments System Innovations in the United States since 1945 and their Implications for Monetary Policy," Chapter 1 in Institutional Change in the Payment System and Monetary Policy, by Stefan W. Schmitz and Geoffrey E. Wood (Routledge).

14. Mikailu., \& Garba.(2005). Treasury Single Account: concept, design and implementation issues. International monetary fund.

15. Udo, B. (2016). 15 things to know about Treasury Single Account. Premium Times.

16. Charles. L. (1980). "Setting Up a Treasury in Economies in Transition," IMF Working Paper 95/16 (Washington: International Monetary Fund)

17. Johnson. (2012). The Essentials of Public Finance and Public Financial Management in Nigeria Calabar: University of Calabar Press

18. Vahyala, P., \& Minnnessi. (2016). "TSA is fraud". www.Sunnewsonline.com Retrieved 22January 2016.

19. Dlakwa. (2014). Treasury Single Account: Giving Life to Jonathan's 'Dead' Policy Directives', Sunday Guardian, August, 16, 52-58 